\title{
Effects of Cultivation Methods on Yield and Essential Oils of Chrysanthemum indicum L. (Gamgug)
}

\author{
Chang Hoon Lee ${ }^{1)}$ and Kyung Dong Lee ${ }^{2) *}$ \\ ${ }^{1)}$ Departments of Functional Crops Science, NICS, RDA, Milyang, 627-130, South Korea \\ ${ }^{2)}$ Department of Oriental Medicine Materials, Dongshin University, Naju, 520-714, South Korea \\ (Received November 24, 2008, Accepted December 22, 2008)
}

\begin{abstract}
Chrysanthemum indicum L. (Gamgug) has been examined to study their flowering habits, yields and bioactive compounds under different planting densities and mowing dates. The planting density experiment revealed a significantly increasing stem diameter, number of flowers and branches with decreasing plant density in the $100 \mathrm{~cm} \times 30 \mathrm{~cm}$ and $130 \mathrm{~cm} \times 30 \mathrm{~cm}$ treatments as compared to $70 \mathrm{~cm} \times$ $30 \mathrm{~cm}$ treatments, but not plant height, leaf and flower width. On the other hand, the mowing date experiment showed that growth characteristics of plants were similar to the control plants (not mowing) and June 20 treatment, but July 20 treatments had significantly smaller than the control. The weights (g plant $\left.{ }^{-1}\right)$ of dry flowers were affected by the planting density and mowing date. The flower yield of $586 \mathrm{~kg} \mathrm{ha}^{-1}$ obtained at $100 \mathrm{~cm} \times 30 \mathrm{~cm}$ density was $11 \%$ and $22 \%$ higher than that of $120 \mathrm{~cm} \times 30 \mathrm{~cm}$ and $70 \mathrm{~cm}$ x $30 \mathrm{~cm}$ treatments, respectively. The yield of dry flowers in the control and June 20 mowing date ranged 495-508 $\mathrm{kg} \mathrm{ha}^{-1}$, which is $40-42 \%$ higher than the yield in the July 20 treatments. The amount of essential oil ( $\left(\right.$ plant $\left.^{-1}\right)$ in medically valuable flowerheads of $C$. indicum $\mathrm{L}$. was statistically different between mowing dates but not among planting densities. The study showed that planting density and the mowing date could increase yields of flowerheads. An optimum planting density of $100 \mathrm{~cm} \times 30 \mathrm{~cm}$ and mowing date of on or before June 20 is recommended for $C$. indicum $\mathbf{L}$.
\end{abstract}

Key Words: C. indicum L., growth, yield, planting density, mowing date, essential oil

\section{INTRODUCTION}

Wild Chrysanthemum has been used for natural medicine for food as well as a gardening flower since the ancient times ${ }^{1)}$. Chrysanthemum spp., a perennial herb which belongs to the Compositae, blooms from October to November throughout Korea with yellow flowered capitulums ${ }^{2}$. In particular, Chrysanthemum indicum L. (Gamgug) (hereafter, C. indicum L.) is known to have several biological actions, such as headache and dizziness medicine peripheral analgesic properties, lowering blood pressure ${ }^{3)}$, anticancer and antibacterial activities $^{4)}$ as well as anti-inflammatory activities ${ }^{6}$. These are due to significant amount of terpene compounds,

*Corresponding author:

Tel: +82-61-330-3261 Fax: +82-61-330-3309

E-mail: leek-d@hanmail.net especially sesquiterpenes, and their derivates ${ }^{4)}$. These immediate constituents were well known as phenolic compounds; luteolin, apigenin, luteolin 7-O- $\beta$-D-glucoside, and as sesquiterpene lactone; cumambrin $\mathrm{A}$, cumambrin $\mathrm{B}$, arteglasin A and angeloyljadin ${ }^{5}$. Several studies on the volatile flavor components have been reported ${ }^{7-9)}$. Chang and $\mathrm{Kim}^{7}$ reported that the yield of $\mathrm{C}$. indicum L. flower oil contained $2.0 \%(\mathrm{w} / \mathrm{w})$ of golden yellow color, and constituted 63 volatile flavor components, which make up $89.28 \%$ of the total aroma composition. In recent years, demands for flowerheads of C. indicum L. as medicinal plants have increased with growing concerns for health-improving foods. But these amounts, which are taken from the wild in mountainous areas, are not enough to satisfy such demands until now. However, the wild C. indicum $\mathrm{L}$. supply should be supplemented by cultivating the crop employing different methods to fulfill the 
increasing demand for a high quality flower. Although some cultivation system studies in Chrysanthemum spp. had been reported, until recently, the results are limited. In cultivation methods, planting densities and mowing dates have a profound effect on factors affecting crop productivity such as absorption of light, water, and nutrients. Although Song et al. ${ }^{10)}$ has reported that pinching on May 20 increased the number of flowers per plant in $C$. indicum L. as compared with June, July and August pinching, until now, very few studies on plant densities and mowing dates in C. indicum L. were conducted. Therefore, various studies on cultivation methods in flowerheads of C. indicum L. are needed. This paper investigated the effects of planting densities and mowing dates on the growth, yield and essential oil contents to develop cultivation methods for high quality of flowerheads of $C$. indicum $\mathrm{L}$.

\section{MATERIALS AND METHODS}

\section{Field experiments}

A field experiment was conducted in 2001 at the Gyeongsang National University. The experimental methods reported similar with $C$. boreale $\mathrm{M}^{12}$. Soil texture was silt loam (SL) with $3.2 \mathrm{~g} \mathrm{~kg}^{-1}$ of $\mathrm{OM}, 3.2$ and $0.97 \mathrm{cmol}^{(+)} \mathrm{kg}^{-1}$ of exchangeable $\mathrm{Ca}$ and $\mathrm{K}$, and a $\mathrm{pH}$ of 5.3. The same levels of $150-80-80 \mathrm{~kg} \mathrm{~N}-\mathrm{P}_{2} \mathrm{O}_{5}-\mathrm{K}_{2} \mathrm{O}$ $\mathrm{ha}^{-1}$ chemical fertilizers were applied to all treatments. The fertilizers were broadcasted in the field one week before the seedlings. All phosphate was applied as basal fertilizer; nitrogen and potassium were splitted, $70 \%$ as basal and $30 \%$ applied around 25 days before flowering. Plots were arranged in a completely randomized design and each treatment was carried out in triplicate. The seedlings of $C$. Indicum L were transplanted on May 25, 2001, and the field was mulched with black vinyl for early weed control. The three examined planting densities were $70 \mathrm{~cm} \times 30 \mathrm{~cm}, 100 \mathrm{~cm} \times 30$ $\mathrm{cm}$ and $130 \mathrm{~cm} \times 30 \mathrm{~cm}$. Plants in mowing dates experiment were mowed at $15 \mathrm{~cm}$ above soil surface considering three dates-treatments: no mowing (control), June 20, and July 20. The flower yield was determined at full bloom stage on October 20, 2001 and the picked fresh flowers before full blooming stage (October 10-15) were put immediately into deepfreezer $\left(-70^{\circ} \mathrm{C}\right)$ for determination of essential oils contents. The growth and yield characteristics were investigated by the RDA methods ${ }^{13)}$.

\section{Analysis of essential oils}

Essential oil contents of C. indicim L. flowerheads were determined with simultaneous distillation extraction (SDE) apparatus, using a modification of various methods ${ }^{12,14-15)}$. Briefly, diethyl ether extracts were separated with a Supelcowax 10 fused silica capillary column (length $60 \mathrm{~m} \mathrm{x}$ inside diameter $0.32 \mathrm{~mm} \times$ film thickness 0.25 um on a Hewlett-Packard 5880 gas chromatograph equipped with a FID detector. The operating conditions of GC were as follows: oven temperature was held at $50^{\circ} \mathrm{C}$ for $5 \mathrm{~min}$, than programmed to increase at $3{ }^{\circ} \mathrm{C} \mathrm{min}{ }^{-1}$ to $225^{\circ} \mathrm{C}$ where it was maintained for $30 \mathrm{~min}$. The injector and ion detector temperatures were 225 and $230^{\circ} \mathrm{C}$, respectively. The flow rate of the carrier gas, nitrogen, was $1.86 \mathrm{ml} \mathrm{min}^{-1}$. Peak areas were measured by electronic integration. The relative amounts of the individual components are based on the peak areas. MS spectra were determined by GC-MSD (HP5890 and HP5970, HewlettPackard, USA), with the electron impact source operating at $70 \mathrm{eV}$ and $240^{\circ} \mathrm{C}$. The injector and ion source detector temperatures were the same as above. Terpene compounds were identified by computer matching of the mass spectra and confirmed by GC retention times.

\section{Statistical analysis}

All data were analyzed statistically by the analysis of variance using CoStat software (CoHort Software, Monterey, USA). Yields and essential oil contents were tested in the experiment using a randomized complete block model with three replications. Mean comparisons were determined using an ANOVA protected least significant difference (LSD) $(\mathrm{P}<0.05)$ test.

\section{RESULTS AND DISCUSSION}

\section{Planting density}

The effects of planting density on growth characteristics and dry matter of C. indicum L. are presented in Table 1 . The number of $1^{\text {st }}$ and $2^{\text {nd }}$ lateral branches in the $100 \mathrm{~cm} \times 30 \mathrm{~cm}$ and $130 \mathrm{~cm} \times 30 \mathrm{~cm}$ plating densities increases with decreasing planting density 
Table 1. Effect of planting density on growth characteristics and biomass of $C$. indicum $\mathrm{L}$.

\begin{tabular}{|c|c|c|c|c|c|c|c|c|c|c|}
\hline \multirow{2}{*}{ Treatment } & \multirow{2}{*}{$\begin{array}{l}\text { Plant } \\
\text { height } \\
(\mathrm{cm})\end{array}$} & \multicolumn{2}{|c|}{$\begin{array}{c}\text { No. of lateral } \\
\text { branches }\end{array}$} & \multirow{2}{*}{$\begin{array}{l}\text { Leaf width } \\
\qquad(\mathrm{cm})\end{array}$} & \multirow{2}{*}{$\begin{array}{c}\text { Stem } \\
\text { diameter } \\
(\mathrm{cm})\end{array}$} & \multirow{2}{*}{$\begin{array}{c}\text { No. } \\
\text { flower } \\
\text { branch }\end{array}$} & \multirow{2}{*}{$\begin{array}{l}\text { Flower } \\
\text { width } \\
(\mathrm{cm})\end{array}$} & \multirow{2}{*}{$\begin{array}{l}\text { Number } \\
\text { of flower }\end{array}$} & \multirow{2}{*}{$\begin{array}{l}\text { Blooming } \\
\text { time }\end{array}$} & \multirow{2}{*}{$\begin{array}{l}\text { Dry weight } \\
\text { of flower } \\
\text { (g plant }{ }^{-1} \text { ) }\end{array}$} \\
\hline & & 1 st & 2nd & & & & & & & \\
\hline $70 \mathrm{~cm} \times 30 \mathrm{~cm}$ & 125 & 18.8 & 99.7 & 43.6 & 1.47 & 12.6 & 114 & 1989 & 10.22 & 9.5 \\
\hline $100 \mathrm{~cm} \times 30 \mathrm{~cm}$ & 131 & 24.0 & 137.3 & 51.7 & 1.75 & 15.7 & 127 & 2503 & 10.22 & 17.6 \\
\hline $130 \mathrm{~cm} \times 30 \mathrm{~cm}$ & 128 & 25.6 & 146.0 & 55.3 & 1.81 & 16.5 & 125 & 2846 & 10.22 & 17.9 \\
\hline $\mathrm{LSD}_{0.05}$ & $\mathrm{~ns}^{1)^{-}}$ & 2.45 & 15.6 & ns & 0.26 & 3.11 & ns & 268 & ns & 1.48 \\
\hline
\end{tabular}

$\mathrm{ns}^{1)}$ : not significant different

Means separation within columns by LSD $(p=0.05, n=3)$

compared to the $70 \mathrm{~cm} \times 30 \mathrm{~cm}$ treatment. This result is similar to those of Lee et al. ${ }^{16)}$ who reported that the planting density in $C$. boreale $M$. had significant effect on the number of lateral branches. Furthermore, stem diameter, number of flower number and branches also significantly increased with decreasing planting density compared to $70 \mathrm{~cm} \times 30 \mathrm{~cm}$ treatment, but not plant height, leaf width and flower width. These results are similar with those of $C$. morifolium plant investigated earlier ${ }^{17}$. On the other hand, plant spacing significantly influenced the number of branches and number of flowers per plant. Blooming time in all treatments was mainly on October 22. The weights ( $g$ per plant) of dry flowers were affected by planting density. Less dense planting density tends to increase the weight of dry matter of shoot parts. The dry weight (17.6 g per plant) of flower in the $100 \mathrm{~cm} \times 30$ $\mathrm{cm}$ treatment was similar to $17.9 \mathrm{~g}$ per plant in the $130 \mathrm{~cm} \times 30 \mathrm{~cm}$ treatment, but significantly higher than the dry weight of flower in the $70 \mathrm{~cm} \times 30 \mathrm{~cm}$. This means that $70 \mathrm{~cm} \times 30 \mathrm{~cm}$ treatment has inhibited air flow by the high planting density. As a result, the dry weight of flower heads and leaves was seriously decreased caused by plant diseases such as powder and downy mildew, which were observed to be more prevalent in the densely spaced crop. As shown in Fig. 1, the yield $\left(\mathrm{kg} \mathrm{ha}^{-1}\right)$ of dry flowers in the $100 \mathrm{~cm} \times 30 \mathrm{~cm}$ density was greater than that in the $70 \mathrm{~cm} \times 30 \mathrm{~cm}$ or $130 \mathrm{~cm} \times 30 \mathrm{~cm}$ treatments. The weight of dry flowers at the $100 \mathrm{~cm} \times 30 \mathrm{~cm}$ density was $586 \mathrm{~kg} \mathrm{ha}^{-1}$, which is 11 and $22 \%$ higher as compared with those of the $120 \mathrm{~cm} \times 30 \mathrm{~cm}$ and $70 \mathrm{~cm}$ $x 30 \mathrm{~cm}$ treatments, respectively. The yield advantage of a $100 \mathrm{~cm} \times 30 \mathrm{~cm}$ planting density over the other can be primarily attributed to the greater number of branches per plant. Therefore, the optimum planting

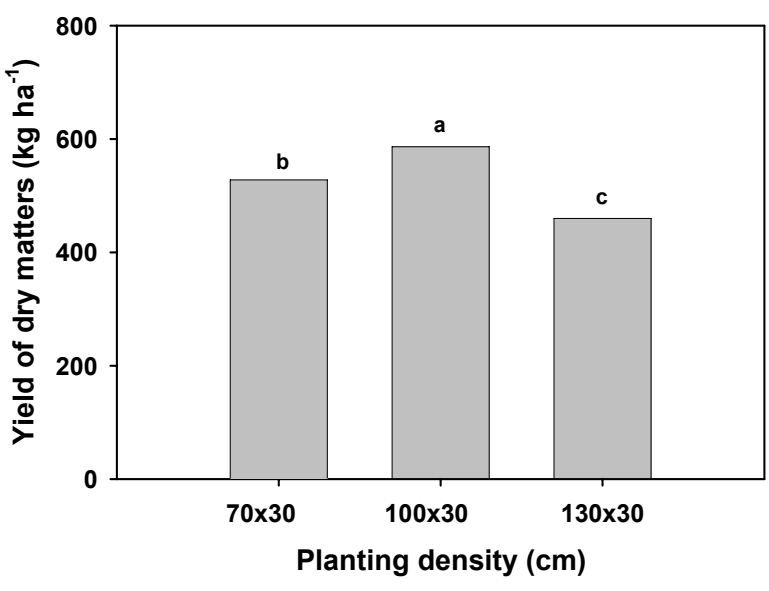

Fig. 1. Dry matter yield of $C$. indicum $L$. flowerheads as affected by planting density. Means with the same letter are not significantly different by $\operatorname{LSD}(p=0.05, n=3)$

density of C. indicum L. plant was considered to be a $100 \mathrm{~cm} \times 30 \mathrm{~cm}$. C. indicum L. flower heads oil have physicochemical and bio-functional properties which are useful and important materials for industrial and medicinal purposes. The yield of essential oils of $C$. indicum L. flowerheads, as shown in Fig. 2, was affected by planting density. The $100 \mathrm{~cm} \times 30 \mathrm{~cm}$ density gave an essential oils yield of $6.5 \mathrm{~kg} \mathrm{ha}^{-1}$, which is 15 and $27 \%$ more as compared with that of the $70 \mathrm{~cm} \times 30 \mathrm{~cm}$ and $120 \mathrm{~cm} \times 30 \mathrm{~cm}$ treatments. The yield of essential oil contents in medically valuable flowerheads of C. indicum L., along with their relative percentage, as affected by planting density, are given in Table 2. The major components of the essential oils isolated were; a-pinene, 1,8-cineol, chrysanthenone, campor, borneol, $\beta$-elemene, germacrene -D, a-curcumene, zingiberene and $\beta$-sisabolene, and occupied approximately $47 \%$ of peak area by GC-MS analyzer. Similar results were reported by Chang and $\mathrm{Kim}^{7}$ that essential oils of $\mathrm{C}$. indicum L. flower 
constituted 63 volatile flavor components, which made up $89.28 \%$ of the total aroma composition. The

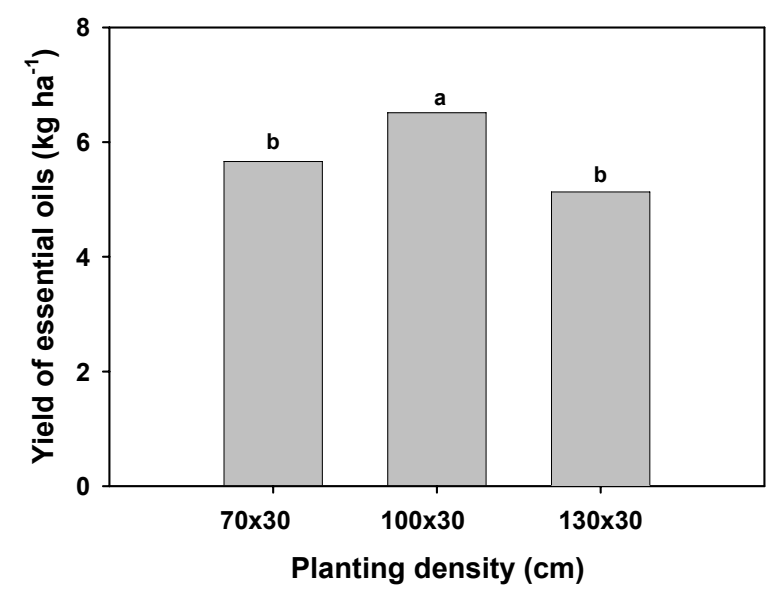

Fig. 2. Yield of essential oils of $C$. indicum L. flowerheads as affected by planting density. Means with the same letter are not significantly different by $\operatorname{LSD}(p=0.05, n=3)$ total peak area of all treatments was not statistically different.

\section{Mowing date}

The mean values of growth characteristics and dry weight (g per plant) of C. indicum L. flowerheads as affected by mowing date are shown in Table 3. Results showed that mowing date has significant influenced on plant height, number of lateral branches, leaf width, stem diameter, number of flower branches, flower width, number of flowers, and blooming time. Similar growth characteristics were observed between the control plants (not mowed) and the mowing at June 20. However, mowing at July 20 had significantly smaller plant height, stem diameter and number of lateral branches than the control. These results are similar to that Lee et al. ${ }^{16)}$ who reported that mowing date in C. boreale $\mathrm{M}$. had

Table 2. Major components (\%) of essential oil of $C$. indicum L. flowerheads as affected by planting density.

\begin{tabular}{|c|c|c|c|c|c|c|}
\hline \multirow{2}{*}{ Compounds } & \multicolumn{2}{|c|}{$60 \mathrm{~cm} \times 30 \mathrm{~cm}$} & \multicolumn{2}{|c|}{$100 \mathrm{~cm} \mathrm{x} 30 \mathrm{~cm}$} & \multicolumn{2}{|c|}{$120 \mathrm{~cm} \mathrm{x} 30 \mathrm{~cm}$} \\
\hline & Mean & $\mathrm{SD}^{1)}$ & Mean & SD & Mean & SD \\
\hline a-pinene & 8.13 & 0.089 & 8.23 & 0.086 & 8.12 & 0.077 \\
\hline 1,8 -cineol & 7.31 & 0.088 & 6.16 & 0.074 & 6.75 & 0.075 \\
\hline chrysanthenone & 10.80 & 0.096 & 10.00 & 0.087 & 11.26 & 0.082 \\
\hline campor & 1.64 & 0.039 & 1.66 & 0.032 & 1.02 & 0.022 \\
\hline borneol & 2.33 & 0.045 & 2.54 & 0.034 & 2.55 & 0.031 \\
\hline$\beta$-elemene & 2.75 & 0.039 & 2.26 & 0.028 & 2.13 & 0.035 \\
\hline germacrene D & 5.05 & 0.065 & 7.02 & 0.058 & 6.09 & 0.069 \\
\hline a-curcumene & 3.85 & 0.032 & 3.56 & 0.036 & 3.78 & 0.022 \\
\hline zingiberene & 2.70 & 0.036 & 2.14 & 0.029 & 2.09 & 0.025 \\
\hline$\beta$-sisabolene & 3.25 & 0.037 & 3.71 & 0.041 & 4.40 & 0.021 \\
\hline Total (\%) & $47.8 \mathrm{a}$ & - & $47.3 \mathrm{a}$ & - & $48.2 \mathrm{a}$ & - \\
\hline
\end{tabular}

$\mathrm{SD}^{1)}:$ standard deviation $(n=3)$

Total values (\%) followed by the same letter are not significantly different using $\mathrm{LSD}_{0.05}$ protected ANOVA

Table 3. Effect of mowing date on growth characteristics and biomass of $C$. indicum $\mathrm{L}$.

\begin{tabular}{|c|c|c|c|c|c|c|c|c|c|c|}
\hline \multirow{2}{*}{ Treatment } & \multirow{2}{*}{$\begin{array}{l}\text { Plant } \\
\text { height } \\
(\mathrm{cm})\end{array}$} & \multicolumn{2}{|c|}{$\begin{array}{l}\text { No. of lateral } \\
\text { branches }\end{array}$} & \multirow{2}{*}{$\begin{array}{l}\text { Leaf width } \\
(\mathrm{cm})\end{array}$} & \multirow{2}{*}{$\begin{array}{l}\text { Stem } \\
\text { diameter } \\
(\mathrm{cm})\end{array}$} & \multirow{2}{*}{$\begin{array}{l}\text { No. of } \\
\text { flower } \\
\text { branch }\end{array}$} & \multirow{2}{*}{$\begin{array}{l}\text { Flower } \\
\text { width } \\
(\mathrm{cm})\end{array}$} & \multirow{2}{*}{$\begin{array}{l}\text { No. of } \\
\text { flower }\end{array}$} & \multirow{2}{*}{$\begin{array}{l}\text { Blooming } \\
\text { time }\end{array}$} & \multirow{2}{*}{$\begin{array}{l}\text { Dry weight } \\
\text { of flower } \\
\left.\text { (g plant }{ }^{-1}\right)\end{array}$} \\
\hline & & $1 \mathrm{st}$ & 2nd & & & & & & & \\
\hline Control $^{1)}$ & 117 & 21.0 & 124.7 & 52.0 & 1.63 & 14.6 & 118 & 2636 & 10.22 & 14.9 \\
\hline June 20 & 107 & 18.7 & 121.3 & 49.7 & 1.55 & 13.7 & 107 & 2569 & 10.22 & 15.2 \\
\hline July 20 & 74 & 10.3 & 81.0 & 41.0 & 1.03 & 9.4 & 83 & 1800 & 10.23 & 8.8 \\
\hline $\mathrm{LSD}_{0.05}$ & 17.2 & 4.3 & 19.1 & 4.8 & 0.19 & 2.9 & 18.7 & 522 & $\mathrm{~ns}^{2)}$ & 2.4 \\
\hline
\end{tabular}

Control $^{1)}$ : Not mowed

$\mathrm{ns}^{2}$ : not significant

Means separation within columns by $\operatorname{LSD}(p=0.05, n=3)$ 


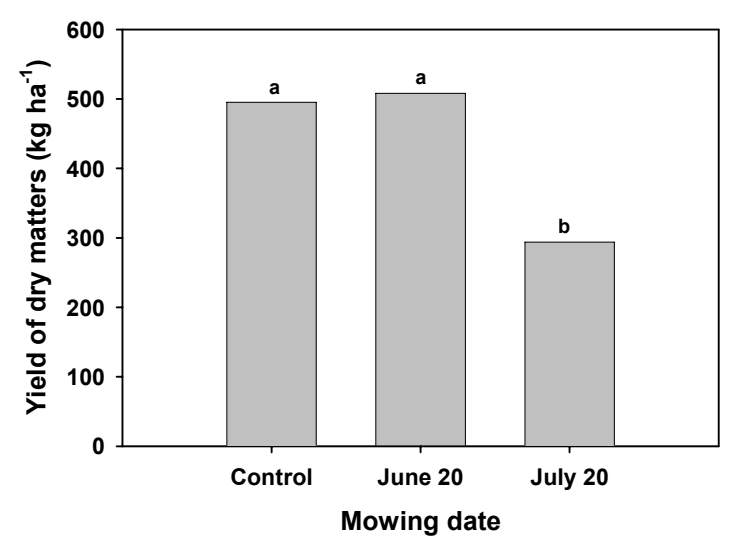

Fig. 3. Dry matter yield of $C$. indicum $\mathrm{L}$. flowerheads as affected by mowing date. Means with the same letter are not significantly different by $\operatorname{LSD}(p=0.05, n=3)$

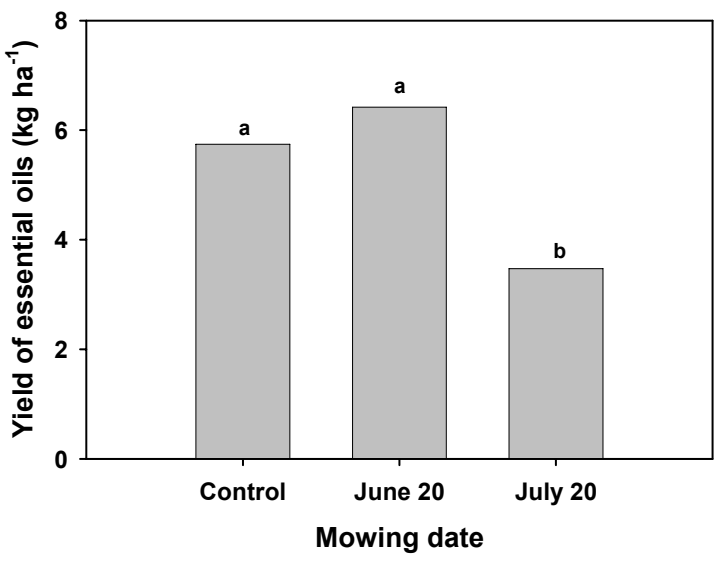

Fig. 4. Yield of essential oils of $C$. indicum L. flowerheads as affected by mowing date. Means with the same letter are not significantly different by LSD $(p=0.05, n=3)$

Table 4. Major component contents (\%) of essential oil of $C$. indicum L. flowerheads as affected by mowing date

\begin{tabular}{ccccccc}
\hline \multirow{2}{*}{ Compounds } & \multicolumn{2}{c}{ Control (not mowed) } & \multicolumn{2}{c}{ June 20 } & \multicolumn{3}{c}{ July 20 } \\
\cline { 2 - 7 } & Mean & SD & Mean & SD & Mean & SD \\
\hline a-pinene & 8.28 & 0.068 & 8.06 & 0.074 & 7.56 & 0.079 \\
1,8-cineol & 6.88 & 0.072 & 6.21 & 0.075 & 5.39 & 0.074 \\
chrysanthenone & 10.50 & 0.075 & 11.42 & 0.086 & 10.88 & 0.098 \\
campor & 1.81 & 0.012 & 2.01 & 0.034 & 2.47 & 0.038 \\
borneol & 2.39 & 0.025 & 2.33 & 0.022 & 2.64 & 0.031 \\
B-elemene & 2.02 & 0.026 & 1.98 & 0.015 & 2.09 & 0.035 \\
germacrene D & 7.55 & 0.053 & 6.68 & 0.056 & 6.25 & 0.023 \\
a-curcumene & 2.87 & 0.036 & 3.51 & 0.026 & 2.15 & 0.025 \\
zingiberene & 2.65 & 0.021 & 3.06 & 0.032 & 2.94 & 0.029 \\
B-sisabolene & 2.20 & 0.018 & 2.17 & 0.038 & 1.86 & 0.016 \\
Total (\%) & $47.2 \mathrm{a}$ & - & $47.4 \mathrm{a}$ & - & $44.2 \mathrm{~b}$ \\
\hline
\end{tabular}

$\mathrm{SD}^{1)}:$ standard deviation $(n=3)$

Total values $(\%)$ followed by the same letter are not significantly different using $\mathrm{LSD}_{0.05}$ protected ANOVA

significant effect on all of treatments. Weights $\left(\mathrm{g}\right.$ plant $\left.{ }^{-1}\right)$ of dry flowers were affected by the mowing date. Especially, plants mowed on July 20 treatments are significantly smaller than those in the control and mowing at June 20. The accumulated dry weights of shoot were similar among all treatments. The weight of dry flowers in the control and mowing at June 20 reached 14.9 and $15.2 \mathrm{~kg} \mathrm{ha}^{-1}$, respectively, a significant increase of approximately $42 \%$ as compared with the mowing at July 20. As shown in Fig. 3, the 495-508 $\mathrm{kg} \mathrm{ha}{ }^{-1}$ yield of dry flowers in the control and mowing at June 20 was $40-42 \%$ higher than that of the mowing at July 20. Therefore, the optimum range of mowing date for $C$. indicum L. plant was on or before June 20. The yield of essential oils of $C$. indicum L. flowerheads as affected by mowing date was presented in Fig. 4. The none-mowing and mowing at June 20 gave statistically identical yield of essential oils in the range of 5.74-6.42 $\mathrm{kg} \mathrm{ha}^{-1}$, which were about $53-71 \%$ higher than those obtained in the mowing at July 20. Table 4 showed that the changes in essential oil contents of the medically valuable flowerhead of C. indicum L. were significantly affected by mowing date.

\section{CONCLUSION}

This study investigated the effects of planting 
densities and mowing dates on the growth, yield and essential oil contents of $\mathrm{C}$. indicum $\mathrm{L}$. in order to develop the cultivation methods for producing high quality flowerheads. Planting density and mowing date can significantly influence the yield of flowerheads. An optimum planting density of $100 \mathrm{~cm} \times 30 \mathrm{~cm}$ and mowing on or before June 20 is recommended for the commercial cultivation of high quality $C$. indicum $\mathrm{L}$.

\section{REFERENCES}

1. Masayodhi, H. (1991) Fragrance materials of the cosmetics. Chrysnathemum 177, 107.

2. Yoon, O.H., and Cho, J.S. (2007) Optimization of extraction conditions for hot water extracts from Chrysanthemum indicum L. by response surface methodology. K. J. Food Cookery Sci. 23, 1-8.

3. Park, N.Y., Kwon, J.H., and Kim, H.K. (1998) Optimization of extraction conditions for ethanol extracts from Chrysanthemum morifolium by response surface methodology. K. J. Food Sci. Technol. 31, 1189-1196.

4. Nam, S.H., and Yang, M.S. (1995) Isolation of cytotoxic substances of extracts from Chrysanthemum boreale M. J. Agric. Food Chem., 38, 273-277.

5. Ryu, S.Y., Choi, S.U., Lee, S.H., Ahn, J.W., and Zee, O.P. (1994) Antitumor activity of some phenolic components in plants. Arch. Pham. Res. 17, 42-44.

6. Cheng, W., Jun, L., You, T., and Hu, C. (2005) Anti-inflammatory and immunomodulatory activities of the extracts from the inflorescence of Chrysanthermum indicum Linne. J. Ethnopharmacol. 101, 334-337.

7. Chang, K., and Kim, G, (2008) Volatile Aroma Composition of Chrysanthemum indicum L. Flower Oil. Food Sci. Nutr. 13, 122-127.

8. Byun, Y.H., and Shin, S. (2008) Analysis of composition and activity of essential oil from Chrysanthermum zawadskii var. latilobum and C. indicum against antibiotic-resistant pathogenic bacteria. Natural Product
Sciences 14, 138-142.

9. Shunying, Z., Yang, Y., Huaidong, Y., Yue, Y., and Guolin, Z (2005) Chemical composition and antimicrobial activity of the essential oils of Chrysanthemum indicum. J. Ethnopharmacol. 96, 151-158.

10. Song, J.S., Lee, M.S., and Hong, Y.P. (1990) Studies on the regulation of growth and flowering of Korea indigenous budding plants. Research Reports of the Rural Development Administration, Horticulture 32, 44-53.

11. Jhon, A.Q., and Paul, T.M. (1995) Influence of spacing and pinching treatments on growth and flower production in Chrysanthemum morifolium R., Progressive Horticulture 27, 57-61.

12. Lee, K.D., Yang, M.S., Supanjani, and Smith, D.L. (2005) Fertilizer effect on the yield and terpene components from the flowerheads of Chrysanthemum boreale M. (Compositae). Agron. Sustain. Dev. 25, 205-211.

13. RDA (Rural Development Administration, Korea) (1995) Standard investigation methods for agricultural experiment. RDA, Suwon, Korea, p. 601.

14. Pino, P.A., Chris, D.B., and Maria, J.P. (2001) Antifungal activity of the essential oil of flowerheads of garland chrysanthemum against agricultural pathogens. Phytochemistry 57, 99-102.

15. Schultz, T.H., Flath, R.A., Mon, T.R., Eggling, S.B., and Tweauishi, R. (1977) Isolation of volatile components from a model system. J. Agric. Food Chem., 25, 446-451.

16. Lee, H.K., Sivanesan, I., and Jeong, B.R. (2008) Effect of planting density, pinching and mowing on plant growth and development of Chrysanthemum boreale Mak. Flower Res. J. 16, 23-27.

17. Jhon, A.Q., and Paul, T.M. (1995) Influence of spacing and pinching treatments on growth and flower production in chrysanthemum (Chrysanthemum morifolium Ramat) cv. Flirt. Progressive Hort. 27, 57-61. 